\title{
KEBIJAKAN PEMBERIAN GANTI KERUGIAN DALAM PENGADAAN TANAH BAGI PEMBANGUNAN UNTUK KEPENTINGAN UMUM
}

\author{
Rahayu Subekti , SH MHum \\ Fakultas Hukum Universitas Sebelas Maret \\ email: rahayusubekti@yahoo.co.id
}

Abstract

\begin{abstract}
The policy on the land procurement matters for the development for public interest has been governed in 1945 Constitution, Indonesia's Law Number 5 of 1960 on The Agrarian Affairs and Indonesia's Law Number 2 of 2012 on The Land Procurement for the Development for Public Interest, President Regulation Number 148 of 2015 about the Fourth Amendment to Perpres Number 71 of 2012 about Land Procurement Implementation for the Development for Public Interest. The research method used in this research is normative juridical approach method. We have a conclusion describing that compensation was given by means of giving reasonable and just compensation to those deserved in the land procurement process. The assessment on the compensation value was conducted by Assessor in land field by field. Recommendation, In compensation discussion, the consensus should be achieved as much as possible.
\end{abstract}

Keywords: Compensation Policy, Land Procurement, Public Interest.

\begin{abstract}
Abstrak
Kebijakan dalam pengadaan tanah bagi pembangunan untuk kepentingan umum diatur dalam Undang - Undang Dasar Negara Republik Indonesia Tahun 1945, Undang-Undang Nomor 5 Tahun 1960 tentang Peraturan Dasar Pokok-pokok Agraria (UUPA) dan Undang Undang Nomor 2 Tahun 2012 Tentang Pengadaan Tanah.bagi Pembangunan untuk Kepentingan Umum, Peraturan Presiden (Perpres) Nomor 148 Tahun 2015 tentang Perubahan Keempat atas Perpres Nomor 71 Tahun 2012 tentang Penyelenggaraan Pengadaan Tanah Bagi Pembangunan untuk Kepentingan Umum. Metode penelitian dalam penulisan jurnal ini adalah metode pendekatan yuridis normatif. Secara ringkas kesimpulan dari hasil pembahasan adalah pemberian ganti kerugian dilakukan dengan cara penggantian yang layak dan adil kepada pihak yang berhak dalam proses pengadaan tanah. Penilaian besarnya nilai Ganti Kerugian oleh Penilai dilakukan bidang per bidang tanah. Dalam musyawarah pemberian ganti rugi hendaknya sebisa mungkin dicapai kata sepakat sehingga ganti rugi langsung diterima oleh yang berhak tidak perlu dititipkan ke Pengadilan Negeri.
\end{abstract}

Kata Kunci : Kebijakan Ganti Kerugian, Pengadaan Tanah, Kepentingan Umum 


\section{A. Pendahuluan}

Manusia dalam hidup dan kehidupannya, tidak dapat dengan semaunya menasbihkan dirinya tidak tergantung dan lepas dari "tanah". Mulai semenjak manusia lahir hingga matipun tanah akan terus menjadi bagian dari kehidupannya, sebab hal yang paling hakiki sekalipun yakni mati pun manusia butuh tanah. Oleh karenanya tanah menjadi kebutuhan dasar manusia . (Fahlevandlaw, 2016).

Demikian juga dalam pelaksanaan pembangunan Nasional khususnya pembangunan berbagai fasilitas untuk kepentingan umum memerlukan bidang tanah yang sangat luas. Dilain pihak, tanah-tanah yang dibutuhkan tersebut pada umumnya sudah dilekati sesuatu hak atas tanah. Tanpa tanah, pembangunan hanya akan menjadi rencana. Dengan demikian upaya pengadaan tanah untuk keperluan tersebut penanganannya perlu dilakukan dengan sebaik-baiknya dan dilakukan dengan memperhatikan peran tanah dalam kehidupan manusia serta prinsip penghormatan terhadap hak yang sah atas tanah. Tanah, di samping mempunyai nilai ekonomis, juga mempunyai fungsi sosial.

Pasal 6 Undang - Undang Nomor 5 Tahun 1960 menyatakan semua hak atas tanah mempunyai fungsi sosial. Ini dimaksudkan bahwa tidak hanya hak milik tetapi semua hak atas tanah mempunyai fungsi sosial . ini berarti bahwa hak atas tanah apapun yang ada pada seseorang, tidaklah dapat dibenarkan bahwa tanahnya itu akan dipergunakan ( atau tidak dipergunakan ) semata - mata untuk kepentingan pribadinya , apalagi kalau hal itu menimbulkan kerugian bagi masyarakat . Penggunaan tanah harus disesuaikan dengan keadaannya dan sifat daripada haknya hingga bermanfaat baik bagi kesejahteraan dan kebahagiaan yang mempunyainya maupun bermanfaat bagi masyarakat dan Negara. Tetapi dalam keadaan tertentu peraturan tidak berarti bahwa kepentingan perseorangan akan terdesak sama sekali ileh kepentingan umum (masyarakat ). UUPA memperhatikan pula kepentingan- kepentingan perseorangan . Kepentingan masyarakat dan kepentingan perseorangan haruslah saling mengimbangi, hingga akhirnya akan tercapai tujuan pokok: kemakmuran, keadilan dan kebahagiaan bagi rakyat seluruhnya . ( Penjelasan II UU Nomor 5 Tahun 1960).

Beberapa konsekuensi dari asas fungsi sosial dari hak atas tanah ini adalah sebagai berikut (Boedi Harsono, 2007, hal. 229): 
a. Tidak dapat dibenarkan untuk menggunakan atau tidak menggunakan tanah hanya untuk kepentingan pribadi pemegang haknya, apalagi menimbulkan kerugian;

b. Penggunaan tanah harus disesuaikan dengan keadaan dan sifat dari haknya, sehingga bermanfaat baik bagi kesejahteraan dan kebahagiaan yang mempunyai maupun bermanfaat bagi masyarakat dan negara;

c. Penggunaan dan pemanfaatan tanah harus memperhatikan Rencana Tata Ruang maupun instrumen penatagunaan tanah lainnya yang ditetapkan secara sah oleh pihak yang berwenang;

d. Pemegang hak atas tanah wajib memelihara tanah dengan baik dalam arti menambah kesuburan dan mencegah kerusakan tanah tersebut;

e. "merelakan" hak atas tanah dicabut demi kepentingan umum

Selain itu, Pasal 33 Ayat (3) Undang - Undang Dasar Republik Indonesia 1945 menyatakan secara jelas bahwa bumi, air dan kekayaan alam yang terdapat didalamnya dikuasai oleh Negara dan dipergunakan sebesar- besarnya bagi kemakmuran rakyat. Hal ini dengan jelas mengandung amanat konstitutional yang sangat mendasar, yaitu bahwa pemanfaatan dan penggunaan tanah harus dapat mendatangkan kesejahteraan yang sebesar - besarnya bagi seluruh rakyat Indonesia . Hal ini berarti bahwa setiap hak atas tanah, dituntut kepastian mengenai subyek, obyek serta pelaksanaan kewenangan haknya (.Rusmadi Murad dalam Bernhard Limbong, 2007 :75).

Kewenangan pemerintah secara normatif untuk mengatur bidang pertanahan berpijak pada Pasal 33 ayat (3) Undang - Undang Dasar 1945 yang menegaskan bahwa Bumi, air dan kekayaan alam yang terkandung didalamnya dikuasai oleh Negara untuk dipergunakan bagi sebesar - besar kemakmuran rakyat. Kemudian , bunyi pernyataan ini dituntaskan secara kokoh didalam Undang - Undang Nomor 5 Tahun 1960 tentang Peraturan Dasar Pokok - Pokok Agraria ( Lembaran Negara 1960 -104 atau disebut juga Undang - Undang Pokok Agraria / UUPA). (Bernhard Limbong, 2011: 39).

Oleh karenanya khusus untuk pelaksanaan pembangunan untuk kepentingan umum menurut Undang-Undang Nomor 5 Tahun 1960 tentang Peraturan Dasar PokokPokok Agraria, Lembaran Negara Nomor 104 Tahun 1960, Pasal 18 menyebutkan untuk kepentingan umum, termasuk kepentingan Bangsa dan Negara serta kepentingan bersama dari rakyat, hak-hak atas tanah dapat dicabut, dengan memberi ganti kerugian 
yang layak dan menurut cara yang diatur dengan undang - undang. Pasal tersebut dapat dikatakan memberikan jaminan bagi rakyat mengenai hak - haknya atas tanah . Pencabutan hak dimungkinkan tapi diikat syarat - syarat, misalnya harus diberikan ganti kerugian yang layak.

Pasal 1 butir 2 Undang - Undang Nomor 2 Tahun 2012 menyatakan Pengadaaan Tanah adalah kegiatan menyediakan tanah dengan cara memberi ganti kerugian yang layak dan adil kepada yang berhak.

Ganti Kerugian adalah penggantian yang layak dan adil kepada pihak yang berhak dalam proses pengadaan tanah . pihak yang berhak adalah pihak yang menguasai atau memiliki objek pengadaan tanah .

Dari hal tersebut diatas, dimana tanah mempunyai fungsi sosial dan adanya jaminan terhadap hak - hak perseorangan, yang mengikat untuk diadakannya pemberian ganti kerugian terhadap tanah yang digunakan untuk kepenringan umum, maka peneliti tertarik untuk mengetahui bagaimanakah kebijakan ganti rugi dalam pengadaan tanah .

Berdasarkan latar belakang di atas, adapun permasalahan yang diteliti dalam artikel ini adalah bagaimanakah kebijakan pemberian ganti kerugian dalam Pengadaan Tanah bagi pembangunan untuk kepentingan umum?

\section{B. Metode Penelitian}

Metode penelitian dalam penulisan jurnal ini adalah metode pendekatan yuridis normatif. Hukum identik dengan norma - norma tertulis yang dibuat dan diundangkan oleh pejabat atau lembaga yang berwenang. Selain itu juga melihat hukumdari suatu system normatif yang bersifat otonom.terlepas dari kehidupan masyarakat (Rony Hanintjo Soemitro, 1983: 11)

\section{Tinjauan Pustaka}

\section{Hak Menguasai Negara}

Dalam penjelasan umum II angka (1 ) UUPA, hak - hak bersama tersebut pada tingkatan tertinggi diangkat menjadi hak Bangsa Indonesia yang meliputi seluruh wilayah Republik Indonesia . Sifat Komunalistik Religius hak atas tanah didalam UUPA ditunjukkan oleh Pasal 1 yang menyatakan :

(1) Seluruh wilayah Indonesia adalah kesatuan tanah air dari seluruh Rakyat Indonesia, yang bersatu sebagai bangsa Indonesia 
(2) Seluruh Bumi, air dan ruang angkasa termasuk kekayaan alam yang terkandung didalamnya dalam wilayah Republik Indonesia sebagai karunia Tuhan Yang maha Esa adalah Bumi, air dan Ruang angkasa bangsa Indonesia dan merupakan kekayaan nasional .

Lebih lanjut dalam penjelasan Umum II angka (1) UUPA dijelaskan bahwa : bumi air dan ruang angkasa dalam wilayah Republik Indonesia yang kemerdekaannya diperjuangkan oleh bangsa sebagai keseluruhan, menjadi hak pula dari bangsa Indonesia, jadi tidak semata mata menjadi hak dari pemiliknya saja.

Pernyataan bahwa Hak bangsa adalah semacam Hak ulayat berarti bahwa dalam konsepsi hukum tanah nasional, hak tersebut merupakan hak penguasaan atas tanah hanya bersumber pada hak bansa ( Harsono, 1997:215)

Pasal 2 ayat (1) UUPA menyatakan bahwa atas dasar ketentuan dalam Pasal 33 ayat (3) Undang - Undang Dasar dan hal - hal sebagai yang dimaksud dalam Pasal 1, bumi, air dan ruang angkasa, termasuk kekayaan alam yang terkandung didalamnya itu pada tingkatan tertinggi dikuasai oleh Negara sebagai organisasi kekuasaan seluruh rakyat.

Menurut Notonagoro, konsepsi hubungan langsung antara Negara dan tanah itu dapat dibedakan menjadi 3 macam yaitu :

a. Negara sebagai subyek, yang kita persamakan dengan perseorangan, sehingga dengan demikian hubungan Negara dengan tanah itu mempunyai sifat privatrechtelijk. Hak Negara atas tanah sama dengan perseorangan atas tanah.

b. Negara sebagai subyek diberi kedudukan tidak sebagai perseorangan tetapi sebagai Negara, jadi sebagai badan kenegaraan sebagai badan publiekrechttelijk.

c. Hubungan anatara Negara langsung dengan tanah ini sebagai subyek perseorangan dan tidak didalam kedudukannya sebagai Negara yang menjadi personifikasi dari rakyat seluruhnya, sehingga dalam konsepsi ini Negara tidak terlepas dari rakyat, Negara hanya sebagai pendiri menjadi pendukung dari kesatuan 2 rakyat ( Notonagoro, 1984 : 100) 
Negara sebagai organisasi kekuasaan seluruh rakyat diberikan hak untuk menguasai tanah dalam rangka untuk mewujudkan kemakmuran rakyat yang dikenal sebagai hak menguasai Negara. Hak menguasai Negara termaksud dalam pasal 2 ayat (1) UUPA yang memberikan wewenang untuk :

a. Mengatur dan menyelenggarakan peruntukan penggunaan persediaan dan pemeliharaan bumi air dan ruang angkasa

b. Menentukan dan mengatur hubungan - hubungan hukum antara orang orang dengan bumi air dan ruang angkasa tersebut

c. Menentukan dan mengatur hubungan - hubungan hukum antara orang orang dan perbuatan - perbuatan hukum mengenai bumi air dan ruang angkasa.

\section{Pengadaan Tanah}

Pengadaan Tanah adalah kegiatan menyediakan tanah dengan cara memberi ganti kerugian yang layak dan adil kepada pihak yang berhak. Aktivitas pengadaan tanah untuk kepentingan pembangunan secara teoritik didasarkan pada prinsip/asas tertentu dan terbagi menjadi dua subsistem:

1) pengadaan tanah oleh pemerintah karena kepentingan umum;

2) pengadaan tanah oleh pemerintah karena bukan kepentingan umum (komersial).

(Oloan Sitorus, 2004: 5)

Pada hakikatnya pengadaan tanah adalah perbuatan pemerintah untuk memperoleh tanah untuk kepentingan umum yang ditempuh berdasarkan musyawarah untuk mencapai kesepakatan mengenai pelepasan hak dan ganti rugi sebelum ditempuhnya pencabutan hak. Hasil dari musyawarah inilah yang kemudian menjadi dasar bagi pembayaran ganti rugi.

Prinsip atau asas-asas secara konteks hukum pengadaan tanah meliputi:

1. Penguasaan tanah dan penggunaan tanah oleh siapapun dan untuk keperluan apapun harus ada landasan haknya;

2. Semua hak atas tanah secara langsung maupun tidak langsung bersumber pada hak bangsa;

3. Cara untuk memperoleh tanah yang sudah dihaki oleh seseorang/badan hukum harus melalui kata sepakat antar pihak yang bersangkutan; 
4. Dalam keadaan memaksa, jika jalan musyawarah tidak dapat menghasilkan kata sepakat, untuk kepentingan umum, Penguasa (dalam hal ini Presiden) diberi kewenangan oleh hukum untuk mengambil tanah yang diperlukan secara paksa, tanpa persetujuan yang empunya tanah, melalui acara pencabutan hak;

5. Baik dalam acara perolehan tanah atas dasar kata sepakat, maupun dalam acara pencabutan hak, kepada pihak yang telah menyerahkan tanahnya wajib diberikan imbalan yang layak, berupa uang, fasilitas dan/atau tanah lain sebagai penggantinya;

6. Rakyat yang diminta menyerahkan tanahnya untuk proyek-proyek pembangunan berhak untuk memperoleh pengayoman dari Pejabat Pamong Praja atau Pamong Desa. Dalam keadaan memaksa artinya jalan lain yang ditempuh gagal, maka presiden memiliki kewenangan untuk melakukan pencabutan hak tanpa persetujuan subyek hak menurut UU Nomor 20 tahun 1961. (Boedi Harsono, dalam Oloan Sitorus, , 2004: 11.)

Tanah merupakan hal penting dalam kehidupan manusia mengingat sebagian besar kehidupan bergantung pada tanah. Sedemikian penting fungsi dan peran tanah bagi kehidupan manusia maka perlu adanya landasan hukum yang menjadi pedoman dan sebagai bentuk jaminan kepastian hukum, dalam pelaksanaan dan penyelesaian pertanahan, khususnya pada persoalan pengadaan hak atas tanah untuk kepentingan umum (Fauzi Noer, 1997: 7).

3) Ganti Kerugian

Masalah ganti kerugian merupakan hal yang paling penting dalam proses pengadaan tanah. Ganti rugi adalah pemberian ganti atas kerugian yang diderita oleh pemegang hak atas tanah atas beralihnya hak tersebut. Pasal 1 UU Nomor 2 tahun 2012 menyatakan ganti kerugian merupakan penggantian yang layak dan adil kepada Pihak yang berhak dalam proses Pengadaan Tanah. Penetapan besarnya nilai ganti kerugian per bidang tanah ini dilakukan oleh Ketua Pelaksana Pengadaan Tanah berdasarkan hasil penilaian jasa penilai atau penilai publik,

Ganti kerugian diberikan kepada pihak yang berhak berdasarkan hasil penilaian yang ditetapkan dalam musyawarah penetapan ganti kerugian dan/atau putusan Pengadilan Negeri/Mahkamah Agung. Ganti kerugian diberikan kepada 
pihak yang berhak berdasarkan hasil penilaian yang ditetapkan dalam musyawarah penetapan ganti kerugian dan/atau putusan Pengadilan Negeri/Mahkamah Agung

Pihak yang berhak menerima ganti kerugian bertanggung jawab atas kebenaran dan keabsahan bukti penguasaan atau kepemilikan yang diserahkan. Dan bagi ada yang melanggar hal tersebut, akan dikenai sanksi pidana sesuai dengan peraturan perundang-undangan yang berlaku

3. Kepentingan Umum

Kepentingan umum (Publik Interest) menurut Roscoe Pound adalah Kepentingan negara sebagai Badan Hukum, dan Kepentingan negara sebagai penjaga kepentingan masyarakat. (http://em-mizan.blogspot.co.id/2009/11/hukum-adalahsuatu-peraturan-norma.html diakses tanggal 6 - 7-2016).

Pasal 1 Butir 6 Undang - Undang Nomor 2 Tahun 2012 menyatakan Kepentingan Umum adalah kepentingan bangsa, negara, dan masyarakat yang harus diwujudkan oleh pemerintah dan digunakan sebesar-besarnya untuk kemakmuran rakyat.

I Wayan Suandra berpendapat bahwa kepentingan umum pada dasarnya adalah segala kepentingan yang menyangkut kepentingan negara, kepentingan bangsa, kepentingan masyarakat luas dan kepentingan-kepentingan pembangunan yang sifatnya menurut pertimbangan Presiden perlu bagi kepentingan umum (I. Wayan Suandra, 1996 :. 17.)

Kepentingan umum pada hakikatnya tidak dapat mengabaikan kepentingan pribadi, bahkan harus mencirikan hal-hal sebagai berikut:

a. Kepentingan pemilik tanah tidak diabaikan;

b. Tidak menyebabkan pemilik tanah mengalami kemunduran dalam kehidupan selanjutnya baik sosial maupun ekonomi;

c. Pemilik tanah memperoleh manfaat, baik secara langsung maupun tidak langsung penggunaan tanahnya yang dilepaskan haknya;

d. Ada kelayakan ganti kerugian yang diberikan kepada pemilik tanah. ( Soetandyo Wignyosoebroto, 1991: 19. 


\section{Pembahasan}

Negara sebagai organisasi kekuasaan seluruh rakyat diberikan hak untuk menguasai tanah dalam rangka untuk mewujudkan kemakmuran rakyat yang dikenal sebagai hak menguasai Negara. Hak menguasai Negara termaksud dalam Pasal 2 ayat (1) UUPA yang memberikan wewenang untuk :

a. Mengatur dan menyelenggarakan peruntukan penggunaan persediaan dan pemeliharaan bumi air dan ruang angkasa

b. Menentukan dan mengatur hubungan - hubungan hukum antara orang orang dengan bumi air dan ruang angkasa tersebut

c. Menentukan dan mengatur hubungan - hubungan hukum antarn aorang orang dan perbuatan - perbuatan hukum mengenai bumi air dan ruang angkasa.

Berdasarkan kewenangannya tersebut maka Negara, mengatur peruntukan penggunaan persediaan dan pemeliharaan bumi air dan ruang angkasa.

Pasal 18 Undang - Undang Nomor 5 Tahun 1960 tentang Peraturan Dasar Pokok - Pokok Agraria (Lembaran Negara 1960 -104 atau disebut juga Undang - Undang Pokok Agraria / UUPA) menyatakan untuk kepentingan umum, termasuk kepentingan Bangsa dan Negara serta kepentingan bersama dari rakyat, hak-hak atas tanah dapat dicabut, dengan memberi ganti kerugian yang layak dan menurut cara yang diatur dengan undang - undang. Pasal ini dapat dikatakan memberikan jaminan bagi rakyat mengenai hak - haknya atas tanah . Pencabutan hak dimungkinkan tapi diikat syarat - syarat, misalnya harus diberikan ganti kerugian yang layak.

Pengadaan tanah untuk kepentingan umum penanganannya perlu dilakukan dengan sebaik-baiknya dan dilakukan dengan memperhatikan peran tanah dalam kehidupan manusia serta prinsip penghormatan terhadap hak yang sah atas tanah. Tanah, di samping mempunyai nilai ekonomis, juga mempunyai fungsi sosial. Sebagaimana bunyi Pasal 6 Undang-Undang Nomor 5 Tahun 1960: "semua hak atas tanah mempunyai fungsi sosial". Fungsi sosial inilah yang kadang kala mengharuskan kepentingan pribadi atas tanah dikorbankan guna kepentingan umum. Adapun yang dimaksud dengan kepentingan umum adalah kepentingan Negara dan masyarakat pemerintah dan digunakan sebesar - besarnya untuk kemakmuran rakyat. 
Pengadaaan Tanah adalah kegiatan menyediakan tanah dengan cara memberi ganti kerugian yang layak dan adil kepada yang berhak. Kegiatan ini dilakukan dengan tujuan menyediakan tanah bagi pelaksanaan pembangunan guna kesejahteraan dan kemakmuran, bangsa, Negara dan masyarakat dengan tetap menjamin kepentingan hukumpihak yang berhak .

Tidak semua kegiatan pembangunan dapat digolongkan sebagai pembangunan untuk kepentingan umum . Tanah untuk Kepentingan Umum digunakan untuk pembangunan (Pasal 10 Undang - Undang Nomor 2 Tahun 2012):

a. pertahanan dan keamanan nasional;

b. jalan umum, jalan tol, terowongan, jalur kereta api, stasiun kereta api, dan fasilitas operasi kereta api;

c. waduk, bendungan, bendung, irigasi, saluran air minum, saluran pembuangan air dan sanitasi, dan bangunan pengairan lainnya;

d. pelabuhan, bandar udara, dan terminal;

e. infrastruktur minyak, gas, dan panas bumi;

f. pembangkit, transmisi, gardu, jaringan, dan distribusi tenaga listrik;

g. jaringan telekomunikasi dan informatika Pemerintah;

h. tempat pembuangan dan pengolahan sampah;

i. rumah sakit Pemerintah/Pemerintah Daerah;

j. fasilitas keselamatan umum;

k. tempat pemakaman umum Pemerintah/Pemerintah Daerah;

1. fasilitas sosial, fasilitas umum, dan ruang terbuka hijau publik;

m. cagar alam dan cagar budaya;

n. kantor Pemerintah/Pemerintah Daerah/desa;

o. penataan permukiman kumuh perkotaan dan/ataun. kantor konsolidasi tanah, serta perumahanuntuk masyarakat berpenghasilan rendah dengan status sewa;

p prasarana pendidikan atau sekolah pemerintah / pemerintah daerah.

q. prasarana olahraga Pemerintah/Pemerintah Daerah; dan

r. pasar umum dan lapangan parkir umum. 
Pengadaan Tanah untuk kepentingan umum dilaksanakan berdasarkan asas :

a. Kemanusiaan

Yang dimaksud dengan "asas kemanusiaan" adalah Pengadaan Tanah harus memberikan pelindungan serta penghormatan terhadap hak asasi manusia, harkat, dan martabat setiap warga negara dan penduduk Indonesia secara proporsional.

b. Keadilan

Yang dimaksud dengan "asas keadilan" adalah memberikan jaminan penggantian yang layak kepada Pihak yang Berhak dalam proses Pengadaan Tanah sehingga mendapatkan kesempatan untuk dapat melangsungkan kehidupan yang lebih baik

c. Kemanfaatan

Yang dimaksud dengan "asas kemanfaatan" adalah hasil Pengadaan Tanah mampu memberikan manfaat secara luas bagi kepentingan masyarakat, bangsa, dan negara.

d. Kepastian

Yang dimaksud dengan "asas kepastian" adalah memberikan kepastian hukum tersedianya tanah dalam proses Pengadaan Tanah untuk pembangunan dan memberikan jaminan kepada Pihak yang Berhak untuk mendapatkan Ganti Kerugian yang layak.

e. Keterbukaan

Yang dimaksud dengan "asas keterbukaan" adalah bahwa Pengadaan Tanah untuk pembangunan dilaksanakan dengan memberikan akses kepada masyarakat untuk mendapatkan informasi yang berkaitan dengan Pengadaan Tanah.

f. Kesepakatan

Yang dimaksud dengan "asas kesepakatan" adalah bahwa proses Pengadaan Tanah dilakukan dengan musyawarah para pihak tanpa unsur paksaan untuk mendapatkan kesepakatan bersama.

g. Keikutsertaan

Yang dimaksud dengan "asas keikutsertaan" adalah dukungan dalam penyelenggaraan Pengadaan Tanah melalui partisipasi masyarakat, baik secara langsung maupun tidak langsung, sejak perencanaan sampai dengan kegiatan pembangunan.

h. Kesejahteraan 
Yang dimaksud dengan asas kesejahteraan adalah bahwa pengadaan tanah untuk pembangunan. Dapat memberikan nilai tambah bagi kelangsungan kehidupan pihak yang berhak dan masyarakat secara luas.

i. Keberlanjutan

Yang dimaksud dengan asas keberlanjutan adalah kegiatan pembangunan dapat berlangsung secara terus menerus berkesinambungan , untuk mencapai tujuan yang diharapkan.

j. Keselarasan

Yang dimaksud dengan "asas keselarasan" adalah bahwa Pengadaan Tanah untuk pembangunan dapat seimbang dan sejalan dengankepentingan masyarakat dan Negara.

Pengadaan tanah untuk kepentingan umum diselenggarakan Pemerintah. diselenggarakan sesuai dengan:

a. Rencana Tata Ruang Wilayah;

b. Rencana Pembangunan Nasional/Daerah;

c. Rencana Strategis; dan

d. Rencana Kerja setiap Instansi yang memerlukan tanah

Penyelenggaraan Pengadaan tanah untuk kepentingan umum memperhatikan keseimbangan antara kepentingan pembangunan dan kepentingan masyarakat, dilaksanakan dengan pemberian Ganti Kerugian yang layak dan adil.

Ganti rugi adalah penggantian berupa uang atau barang lain kepada seseorang yang merasa dirugikan karena harta miliknya diambil dan dipakai untuk kepentingan orang banyak (https://rubrikbahasa.wordpress.com/2009/04/17/ganti-rugi-dan-ganti$\underline{\text { kerugian}}$. Ganti Kerugian adalah penggantian yang layak dan adil kepada pihak yang berhak dalam proses pengadaan tanah.

Pasal 27 ayat ( 2 ) Undang - Undang Nomor 2 Tahun 2012 Pelaksanaan Pengadaan Tanah meliputi :

a. Inventarisasi dan identifikasi penguasaan, pemilikan, penggunaan, dan pemanfaatan tanah

b. Penilaian Ganti Kerugian

c. musyawarah penetapan Ganti Kerugian; 
d. pemberian Ganti Kerugian; dan

e. pelepasan tanah Instansi

Inventarisasi dan identifikasi penguasaan, pemilikan, penggunaan, dan pemanfaatan tanah sebagaimana dimaksud dalam Pasal 27 ayat (2) huruf a meliputi kegiatan:

a. pengukuran dan pemetaan bidang per bidang tanah; dan

b. pengumpulan data Pihak yang Berhak dan Objek Pengadaan Tanah.

Inventarisasi dan identifikasi dilaksanakan untuk mengetahui Pihak yang Berhak dan Objek Pengadaan Tanah. Hasil inventarisasi dan identifikasi tersebut memuat daftar nominasi Pihak yang Berhak dan Objek Pengadaan Tanah. Pihak yang Berhak meliputi nama, alamat, dan pekerjaan pihak yang menguasai/memiliki tanah. Objek Pengadaan Tanah meliputi letak, luas, status, serta jenis penggunaan dan pemanfaatan tanah.

Inventarisasi dan identifikasi penguasaan, pemilikan, penggunaan, dan pemanfaatan tanah sebagaimana dilaksanakan dalam waktu paling lama 30 (tiga puluh) hari kerja.

Penilaian besarnya nilai Ganti Kerugian oleh Penilai dilakukan bidang per bidang tanah, meliputi:

a. tanah;

b. ruang atas tanah dan bawah tanah;

c. bangunan;

d. tanaman;

e. benda yang berkaitan dengan tanah; dan/atau

f. kerugian lain yang dapat dinilai. (Yang dimaksud dengan "kerugian lain yang dapat dinilai" adalah kerugian nonfisik yang dapat disetarakan dengan nilai uang, misalnya kerugian karena kehilangan usaha atau pekerjaan, biaya pemindahan tempat, biaya alih profesi, dan nilai atas properti sisa).

Setelah penetapan lokasi untuk kepentingan umum, Pihak yang berhak hanya dapat mengalihkan hak atas tanahnya kepada instansi yang memerlukan tanah melalui lembaga pertanahan .beralihnya hak dilakukan dengan memberikan ganti kerugian yang nilainya ditetapkan saat nilai pengumuman penetapan lokasi.

Besarnya nilai Ganti Kerugian berdasarkan hasil penilaian Penilai disampaikan 
kepada Lembaga Pertanahan dengan berita acara. Nilai Ganti Kerugian berdasarkan hasil penilaian Penilai menjadi dasar musyawarah penetapan Ganti Kerugian. Dalam hal bidang tanah tertentu yang terkena Pengadaan Tanah terdapat sisa yang tidak lagi dapat difungsikan sesuai dengan peruntukan dan penggunaannya, Pihak yang Berhak dapat meminta penggantian secara utuh atas bidang tanahnya.

Pasal 36 Undang - Undang Nomor 2 Tahun 2012 menyatakan Pemberian Ganti Kerugian dapat diberikan dalam bentuk:
a. uang;
b. tanah pengganti;
c. permukiman kembali;

Yang dimaksud dengan "permukiman kembali" adalah proses kegiatan penyediaan tanah pengganti kepada Pihak yang Berhak ke lokasi lain sesuai dengan kesepakatan dalam proses Pengadaan Tanah

d. kepemilikan saham; atau

Yang dimaksud dengan "bentuk ganti kerugian melalui kepemilikan saham" adalah penyertaan saham dalam kegiatan pembangunan untuk kepentingan umum terkait dan/atau pengelolaannya yang didasari kesepakatan antarpihak.

e. bentuk lain yang disetujui oleh kedua belah pihak.

Bentuk lain yang disetujui oleh kedua belah pihak misalnya gabungan dari 2 (dua) atau lebih bentuk Ganti Kerugian sebagaimana dimaksud pada huruf a, huruf b, huruf c, dan huruf d.

Terkait ganti kerugian dalam bentuk uang dalam pengadaan tanah, berdasarkan Peraturan Presiden (Perpres) Nomor 148 Tahun 2015 tentang Perubahan Keempat atas Perpres Nomor 71 Tahun 2012 tentang Penyelenggaraan Pengadaan Tanah Bagi Pembangunan untuk Kepentingan Umum, dilakukan oleh instansi yang memerlukan tanah berdasarkan validasi dari ketua pelaksana pengadaan tanah atau pejabat yang ditunjuk. Validasi tersebut dilaksanakan dalam waktu paling lama tiga hari kerja sejak berita acara kesepakatan bentuk ganti kerugian. Pemberian ganti kerugian dilakukan dalam waktu paling lama tujuh hari kerja sejak penetapan bentuk ganti kerugian oleh pelaksana pengadaan tanah.

Lembaga Pertanahan melakukan musyawarah dengan Pihak yang Berhak dalam 
waktu paling lama 30 (tiga puluh) hari kerja sejak hasil penilaian dari Penilai disampaikan kepada Lembaga Pertanahan untuk menetapkan bentuk dan/atau besarnya Ganti Kerugian berdasarkan hasil penilaian Ganti Kerugian . Hasil kesepakatan dalam musyawarah menjadi dasar pemberian Ganti Kerugian kepada Pihak yang Berhak yang dimuat dalam berita acara kesepakatan.

Ganti Kerugian diberikan kepada Pihak yang Berhak berdasarkan hasil penilaian yang ditetapkan dalam musyawarah. Pemberian Ganti Kerugian pada prinsipnya harus diserahkan langsung kepada Pihak yang Berhak atas Ganti Kerugian. Apabila berhalangan,Pihak yang Berhak karena hukum dapat memberikan kuasa kepada pihak lain atau ahli waris. Penerima kuasa hanya dapat menerima kuasa dari satu orang yang berhak atas Ganti Kerugian. Yang berhak antara lain:
a. pemegang hak atas tanah;
b. pemegang hak pengelolaan;
c. nadzir, untuk tanah wakaf;
d. pemilik tanah bekas milik adat;
e. masyarakat hukum adat;

f. pihak yang menguasai tanah negara dengan itikad baik;

g. pemegang dasar penguasaan atas tanah; dan/atau

h.pemilik bangunan, tanaman atau benda lain yang berkaitan dengan tanah.

Pada ketentuannya, Ganti Kerugian diberikan kepada pemegang Hak atas Tanah. Untuk hak guna bangunan atau hak pakai yang berada di atas tanah yang bukan miliknya, Ganti Kerugian diberikan kepada pemegang hak guna bangunan atau hak pakai atas bangunan, tanaman, atau benda lain yang berkaitan dengan tanah yang dimiliki atau dipunyainya, sedangkan Ganti Kerugian atas tanahnya diberikan kepada pemegang hak milik atau hak pengelolaan. Ganti Kerugian atas tanah hak ulayat diberikan dalam bentuk tanah pengganti, permukiman kembali, atau bentuk lain yang disepakati oleh masyarakat hukum adat yang bersangkutan. Pihak yang menguasai tanah negara yang dapat diberikan Ganti Kerugian adalah pemakai tanah negara yang sesuai dengan atau tidak melanggar ketentuan peraturan perundang-undangan. Misalnya, bekas pemegang hak yang telah habis jangka waktunya yang masih menggunakan atau memanfaatkan tanah yang bersangkutan, pihak yang menguasai tanah negara berdasarkan sewa- 
menyewa, atau pihak lain yang menggunakan atau memanfaatkan tanah negara bebas dengan tidak melanggar ketentuan peraturan perundang-undangan. Yang dimaksud dengan "pemegang dasar penguasaan atas tanah" adalah pihak yang memiliki alat bukti yang diterbitkan oleh pejabat yang berwenang yang membuktikan adanya penguasaan yang bersangkutan atas tanah yang bersangkutan, misalnya pemegang akta jual beli atas Hak atas Tanah yang belum dibalik nama, pemegang akta jual beli atas hak milik adat yang belum diterbitkan sertifikat, dan pemegang surat izin menghuni. Bangunan, tanaman, atau benda lain yang berkaitan dengan tanah yang belum atau tidak dipunyai dengan Hak atas Tanah, Ganti Kerugian diberikan kepada pemilik bangunan, tanaman, atau benda lain yang berkaitan dengan tanah.

Pada saat pemberian Ganti Kerugian Pihak yangBerhak menerima Ganti Kerugian wajib:

a. melakukan pelepasan hak; dan

b. menyerahkan bukti penguasaan atau kepemilikan Objek Pengadaan Tanah kepada Instansi yang memerlukan tanah melalui Lembaga Pertanahan.

Pelepasan hak adalah kegiatan pemutusan hubungan hukumdari pihak yang berhak kepada Negara melalui lembaga Pertanahan .

Pasal 42 Undang - Undang Nomor 2 Tahun 2012 menyatakan : Dalam hal Pihak yang Berhak menolak bentuk dan/atau besarnya Ganti Kerugian berdasarkan hasil musyawarah, Ganti Kerugian dititipkan di pengadilan negeri setempat. Penitipan Ganti Kerugian, juga dilakukan terhadap:

a. Pihak yang Berhak menerima Ganti Kerugian tidak diketahui keberadaannya; atau

b. Objek Pengadaan Tanah yang akan diberikan Ganti Kerugian:

1. sedang menjadi objek perkara di pengadilan;

2. masih dipersengketakan kepemilikannya;

3. diletakkan sita oleh pejabat yang berwenang; atau

4. menjadi jaminan di bank.

\section{Simpulan}

Pengadaan tanah bagi pembangunan untuk kepentingan umum merupakan kegiatan menyediakan tanah dengan cara memberi ganti kerugian yang layak dan adil kepada pihak yang berhak. 
Pengadaan tanah diatur dalam Pasal 33 Undang - Undang 1945 , Undang Undang Nomor 5 Tahun 1960 dan Undang - Undang Nomor 2 Tahun 2012 tentang Pengadaan Tanah bagi Pembangunan untuk Kepentingan Umum .Dalam pengadaan tanah dilakukan dengan cara Pelepasan Hak adalah kegiatan pemutusan hubungan hukum dari pihak yang berhak kepada negara melalui Lembaga Pertanahan .

Kebijakan pemberian ganti kerugian dilakukan dengan cara penggantian yang layak dan adil kepada pihak yang berhak dalam proses pengadaan tanah. Penilaian besarnya nilai Ganti Kerugian oleh Penilai dilakukan bidang per bidang tanah, meliputi:

a. tanah;

b. ruang atas tanah dan bawah tanah;

c. bangunan;

d. tanaman;

e. benda yang berkaitan dengan tanah; dan/atau

f. kerugian lain yang dapat dinilai

Pemberian Ganti Kerugian dapat diberikan dalam bentuk:
a. uang;
b. tanah pengganti;
c. permukiman kembali;
d. kepemilikan saham; atau
e. bentuk lain yang disetujui oleh kedua belah pihak.

Bentuk lain yang disetujui oleh kedua belah pihak misalnya gabungan dari 2 (dua) atau lebih bentuk Ganti Kerugian sebagaimana dimaksud pada huruf a, huruf b, huruf c, dan huruf d.

\section{E. Saran}

Dalam musyawarah pemberian ganti rugi hendaknya sebisa mungkin dicapai kata sepakat sehingga ganti rugi bisa langsung diterima oleh yang berhak tidak perlu dititpkan ke Pengadilan Negeri. 


\section{Daftar Pustaka}

Fahlevandlaw. 2016. Politik Hukum Pengadaan Tanah Untuk Kepentingan Umum : Antara Manifestasi Keadilan Sosial dengan Kepentingan Pemerintah bagi Pembangunan, Diakses tanggal 2- 07 -2016.

Harsono, Boedi. 1997. Hukum Agraria Indonesia: Sejarah Pembentukan Undang-Undang Pokok Agraria, Isi dan Pelaksanaannya, Jilid 1 Hukum Tanah Nasional. Jakarta: Djambatan.

Harsono, Boedi. 2007. Hukum Agraria Indonesia: Sejarah Pembentukan Undang-Undang Pokok Agraria, Isi dan Pelaksanaannya, Jilid 1 Hukum Tanah Nasional. Cetakan Kesebelas Edisi Revisi. Jakarta: Djambatan.

Limbong, Bernhard.2011. Pengadaan tanah Untuk Pembangunan ( Regulasi, Kompensasi, Penegakan Hukum. Jakarta: Margaretha Pustaka.

Noer, Fauzi. 1997. Tanah dan Pembangunan. Jakarta: Pustaka Sinar Harapan.

Rusmadi, Murad. 2007. Menyingkap Tabir Masalah Pertanahan. Bandung: Mandar Maju .

Sitorus, Oloan. 2004. Pelepasan atau Penyerahan Hak atas Tanah Sebagai Cara Pengadaan Tanah. Jakarta: Cetakan Pertama. Dasamedia Utama.,

Sitorus, Oloan. 1995. Pengadaan Tanah untuk Kepentingan Umum, Mitra Kebijakan Tanah Indonesia. Yogyakarta.

Soemitro, Rony Hanintjo. 1983. Metodologi Penelitian Hukum. Jakarta: Ghalia Indonesia.

Suandra, I. Wayan. 1996. Masalah Hak Atas Tanah, Pembebasan Tanah dan Pengadaan Tanah Bagi Pelaksanaan Pembangunan Untuk Kepentingan Umum. Bandung: Citra Adtya Bakti.

Umar, Said Sugiharto dkk. 2015. Hukum Pengadaan Tanah ( Pengadaan Hak Atas Tanah untuk Kepentingan Umum Pra dan Pasca Reformasi). Malang: Setara Press.

Wignyosoebroto, Soetandyo. 1991. Pengertian Kepentingan Umum Dalam Pembebasan Hak Atas Tanah. Gema Clipping Service Hukum..

\section{Peraturan:}

Undang-Undang Nomor 5 Tahun 1960 tentang Peraturan Dasar Pokok-Pokok Agraria, Lembaran Negara No. 104 Tahun 1960 
Undang - Undang Nomor 2 Tahun 2012 tentang Pengadaan Tanah Bagi Pembangunan Untuk Kepentingan Umum.

Peraturan Presiden (Perpres) Nomor 148 Tahun 2015 tentang Perubahan Keempat atas Perpres Nomor 71 Tahun 2012 tentang Penyelenggaraan Pengadaan Tanah Bagi Pembangunan untuk Kepentingan Umum

\section{Internet:}

Mizan ,2009, Hukum Definisi Dari para Ahli, http://em-mizan.blogspot.co.id/2009/11/hukumadalah-suatu-peraturan-norma.html diakses tanggal 6 - 7-2016). 